\title{
The Performance of Advanced Sequencing Batch Reactor in Wastewater Treatment Plant to Remove Organic Materials and Linear Alkyl Benzene Sulfonates
}

\author{
Hadi Eslami ${ }^{1}$; Parvaneh Talebi Hematabadi ${ }^{2}$; Seyed Vahid Ghelmani ${ }^{3}$; Akbar Salehi Vaziri ${ }^{2}$; \\ Zahra Derakhshan ${ }^{1, *}$ \\ ${ }^{1}$ Department of Environmental Health, Shahid Sadoughi University of Medical Sciences, Yazd, IR Iran \\ ${ }^{2}$ Department of Environmental Engineering, Meybod Branch, Islamic Azad University, Yazd, IR Iran \\ ${ }^{3}$ Wastewater and Sewage Organization, Water and Wastewater Company, Yazd, IR Iran \\ ${ }^{*}$ Corresponding author: Zahra Derakhshan, Department of Environmental Health, Shahid Sadoughi University of Medical Sciences, Yazd, IR Iran. Tel: +98-9176115365, \\ E-mail: Dr_derakhshan@yahoo.com
}

Received: May 3, 2015; Revised: June 22, 2015; Accepted: June 23, 2015

\begin{abstract}
Background: Linear alkyl benzene sulfonates (LAS) are the most important ionic detergents that produce negative ions in the environment. These compounds enter surface waters through domestic and industrial wastewaters and cause environmental hazards. Objectives: The present study was aimed at assessing the performance of advanced sequencing batch reactor (SBR) in wastewater treatment plant of Yazd, Iran, to remove organic materials and detergents.

Materials and Methods: The present research was a descriptive longitudinal study conducted on 96 input and output samples of SBR system over eight months from October 2012 to June 2013. The studied parameters were biochemical oxygen demand $5\left(\mathrm{BOD}_{5}\right)$, chemical oxygen demand (COD), and detergents (LAS), which were assessed through standard methods. Finally, the study data were analyzed through analysis of variance (ANOVA) using software package for statistical analysis (SPSS).

Results: The mean inputs of $\mathrm{BOD}_{5}, \mathrm{COD}$, and LAS to the SBR system were $292.40 \pm 45.28,597.15 \pm 97.30$, and $3.29 \pm 0.92 \mathrm{mg} / \mathrm{L}$, and the mean outputs were $20.59 \pm 3.54,59.34 \pm 9.47$, and $0.606 \pm 0.09 \mathrm{mg} / \mathrm{L}$, respectively. The removal efficiency of $\mathrm{BOD}_{5}, \mathrm{COD}$ and LAS were respectively $92.95 \%, 90.06 \%$ and $81.6 \%$. The results of ANOVA indicated that there was a significant relationship between the mean inputs and outputs of $\mathrm{BOD}_{5}, \mathrm{COD}$, and the detergents $(\mathrm{P} \leq 0.001)$.

Conclusions: With the proper operation of wastewater the treatment plant and increasing the retention time, the removal efficiency of the detergents increased. In addition, according to the environmental standards for $\mathrm{BOD}_{5}, \mathrm{COD}$ and the detergents, the results of the present study indicated that the outputs of these parameters from the SBR system were appropriate for agricultural irrigation.
\end{abstract}

Keywords: LAS; Wastewater Treatment; Sequencing Batch Reactor

\section{Background}

Due to the rapid increase in the population and the shortage of water resources in recent years, human beings have seriously threatened the wildlife by polluting the water resources. Municipal and industrial wastewaters are among the pollutants of the environment, especially water resources. By entering the surface waters, these pollutants not only endanger human's health and the environment, but also cause biological problems for animals and plants (1). Nowadays, there are a wide variety of wastewater treatment systems; however, sequencing batch reactor (SBR) seems to be the most promising and appropriate modified activated sludge process which can be utilized to remove carbon and nitrogen organic matters (2-5). In recent years, SBR has been widely used to treat industrial and municipal wastewater because of its low cost and suitable efficiency in pollutant removal (6-8). The process is composed of five stages as filling, reaction, settling, effluent and idle $(9,10)$. The intermittent cycle extension aeration system (ICEAS) or advanced SBR process is a variant of an SBR system where the processes of biological oxidation, nitrification, phosphorous removal and liquids/solids separation can be achieved continuously in a single tank. What makes the ICEAS process different is a continuous inflow, even during the settle and decant phases of the operating cycle. Wastewater flow continuously fills up the reactor and discontinuously discharges (11). In this process, wastewater enters the reactor and after physical and biological processes exits. To improve the performance of the process, two or more reactors with predetermined orders are utilized. All the necessary processes in this method are chronologically conducted in a pool. Through alternate use of aerobic and anaerobic processes in the SBR system, large amounts of organic matter and nutrients can be removed $(12,13)$. The SBRs performance is satisfactory in treating domestic wastewater. The quality of effluent has been reported 20 and $5 \mathrm{mg} / \mathrm{L}$ for chemical oxygen demand (COD)

Copyright (C) 2015, Ahvaz Jundishapur University of Medical Sciences. This is an open-access article distributed under the terms of the Creative Commons Attribution-NonCommercial 4.0 International License (http://creativecommons.org/licenses/by-nc/4.0/) which permits copy and redistribute the material just in noncommercial usages, provided the original work is properly cited. 
and biochemical oxygen demand $5\left(\mathrm{BOD}_{5}\right)$, respectively, by Lamine et al. (14). Zhou et al. (15) studied the capability of SBR in treating landfill leachate. The study resulted in up to $94 \%$ and $98 \%$ of $C O D$ and BOD $_{5}$ removal. In another study by Goncalves et al. (16) a SBR unit operated for organic removal from wool dyeing effluent. COD and $\mathrm{BOD}_{5}$ removal rates were $85 \%$ and $95 \%$, respectively. The SBR system can be used in biological treatment of different types of industrial and municipal wastewaters (17). Different studies have been conducted on treatment of biological wastewater of olive oil industry (18), wastewaters containing antibiotics (19), removal of cyanide from wastewater of electroplating industry (20), textile industry wastewater (21), wastewaters containing phenol (22), coal industry wastewaters (23), wastewaters with high concentrations of nitrogen (12), and domestic wastewaters and waste leachate (24).

More than 100,000 synthetic chemicals such as detergents are used in a variety of domestic and industrial applications and numerous studies have documented that many of these compounds are incompletely degraded or removed during wastewater treatment and are persistent in the aquatic environment (25). Detergents are a group of chemicals that have cleansing properties. These compounds have a polar hydrophilic group and a nonpolar hydrocarbon branch (hydrophobic) (26). These compounds enter surface waters through domestic and industrial wastewaters and cause environmental hazards. Linear alkyl benzene sulfonates (LAS) are the most important ionic detergents which produce negative ions in the environment. LASs are utilized in household detergents like washing powder, dishwashing detergent, etc. $(17,18)$. In aquatic environment, detergents float on the surface of water as a surface layer and disfigure the aquatic environment, reduce gas exchange and endanger the aquatic animals' health by decreasing the dissolved oxygen. These compounds change the taste and smell of the water, produce fume on the surface of water, cause disruption in the process of water and wastewater treatment, increase the treatment costs, and lead to aquatic animals' death (27-30).

\section{Objectives}

Due to the appropriate properties of the SBR system for wastewater treatment and the inefficiency of other wastewater treatment systems of Yazd in removing detergents, Yazd's company of water and wastewater has designed an Advanced SBR system to treat the municipal wastewater. In this regard, the present study was conducted to determine the performance of advanced SBR in Yazd wastewater treatment plant to remove organic materials and detergents.

\section{Materials and Methods}

\subsection{Wastewater Characteristics}

Raw wastewater with the following qualitative and quantitative properties was fed to the SBR system in the Yazd wastewater treatment plant.

\subsection{The Schematic of Yazd Wastewater Treatment Plant}

In this system, before wastewater enters the SBR system, it passes two initial treatment units consisting of a screening and a grit chamber and is then discharged into the reactors. In this process, six SBRs are simultaneously employed. The dimension of each reactor was as follows: the length 40 meters, the width 23.75, and the depth 6.6 meters. Afterwards, inside each reactor, mixing operation with a retention time of 0.9 hour and aeration operation with a retention time of 2.5 hours get conducted. When the biological treatment ends, sedimentation operation with a retention time of one hour begins and lasts until complete discharge of clarified effluent with a retention time of half an hour. All of these phases are conducted in one reactor and the total retention time is 4.9 hours. Extra sludge is also discharged from the system in each treatment period.

\subsection{Sampling and Experiments}

The present research was a descriptive longitudinal study conducted over eight months. Composite sampling was carried out on a daily basis from October 2012 to June 2013. In this regard, special containers (1 L) for wastewater sampling were utilized to collect samples from the input and output of the SBR system in Yazd wastewater treatment plant. Therefore, six samples per month and 48 samples during the eight-month period from the output and 48 samples from the input of the plant, equal to a total of 96 samples were collected for further analysis and examination.

The experiments conducted on the samples included $\mathrm{BOD}_{5}$, COD, and detergents (LAS). After sampling, the samples were taken to the chemistry laboratory of the faculty of health, Shahid Sadoughi university of medical sciences, Yazd, and the abovementioned parameters were measured according to the guidelines of the standard methods (31). Due to the importance of measuring the detergents, the measurement method is explained below.

The utilized materials and instruments included chloroform, sodium hydroxide, phenolphthalein index solution, standard LAS solution, $1 \mathrm{~N}$ sulfuric acid, standard stock solution of LAS, detergent, and separating funnels. First, the sample wastewaters were spilled into the separating funnels, and then by adding drops of $1 \mathrm{~N} \mathrm{NaOH}$ and using 10 drops of phenolphthalein, the solutions became alkaline. The pink color was removed by adding drops of $\mathrm{H}_{2} \mathrm{SO}_{4}$. To prevent the formation of emulsion, $10 \mathrm{~mL}$ chloroform, $25 \mathrm{~mL}$ blue methylene and $10 \mathrm{~mL}$ isopropyl alcohol were added to the samples. The funnels were shaken for 30 minutes so that the phases would separate. By tilting the funnels and opening their valves slowly, the accumulated pressure 
was released. Some samples needed more time to separate. Before the chloroform layers were discharged, the samples were shaken slowly so that they could settle. Therefore, the chloroform phase placed at the bottom and the aqueous phase positioned on top. After the layers separated, the chloroform layer was spilled into another separating funnel and the first funnel tube was washed with some chloroform. Afterwards, by adding $10 \mathrm{~mL}$ of chloroform in each cycle, the extraction was repeated three times. All of the resulting substances from the chloroform extraction were spilled in the second funnel; then, $50 \mathrm{~mL}$ detergent solution was added and the funnel was severely shaken for 30 minutes. No emulsion was formed in this solution. After sedimentation, the contents were shaken and the chloroform layer, separated from the aqueous layer, was transmitted to a $10-\mathrm{mL}$ volumetric flask. The detergent solution was again extracted using $10 \mathrm{~mL}$ chloroform and the result was added to the previous volumetric flask. This process was repeated once more to make sure about the precision of the experiment and the volume of the extracted chloroform reached $100 \mathrm{~mL}$ after it was spilled into the volumetric flask. Afterwards, the cap of the flask was replaced and it was slightly turned to prevent sedimentation. Prior to the final measurements, the flask was turned several times to mix the contents. The absorptions of the standard samples were measured against the control chloroform at $652 \mathrm{~nm}$ using a spectrophotometer. Using the prepared standard absorption rate and concentration, the calibration curve was drawn and the LAS concentration was measured (31). Finally, the collected data were analyzed through analysis of variance (ANOVA) using software package for statistical analysis (SPSS) version 18.0.

\section{Results}

The results of the experiments of input and output $\mathrm{BOD}_{5}$, COD and detergents are presented in Tables 2 and 3. The removal percentages of these parameters are indicated in Figures 1 and 2.

The results indicated that during the eight-month period, the removal efficiencies of BOD $_{5}$ and COD were $92.95 \%$ and $90.06 \%$, respectively. ANOVA also showed that there was a significant relationship between the input and output means of $\mathrm{BOD}_{5}$ and $\mathrm{COD}(\mathrm{P} \leq 0.001)$.

The results indicated that the total mean of the detergents decreased from 3.29 to 0.6. ANOVA also showed that there was a significant relationship between the input and output means of the detergents $(\mathrm{P} \leq 0.001)$. Moreover, the mean removal rate of the detergents was $81.6 \%$ (Table 3).

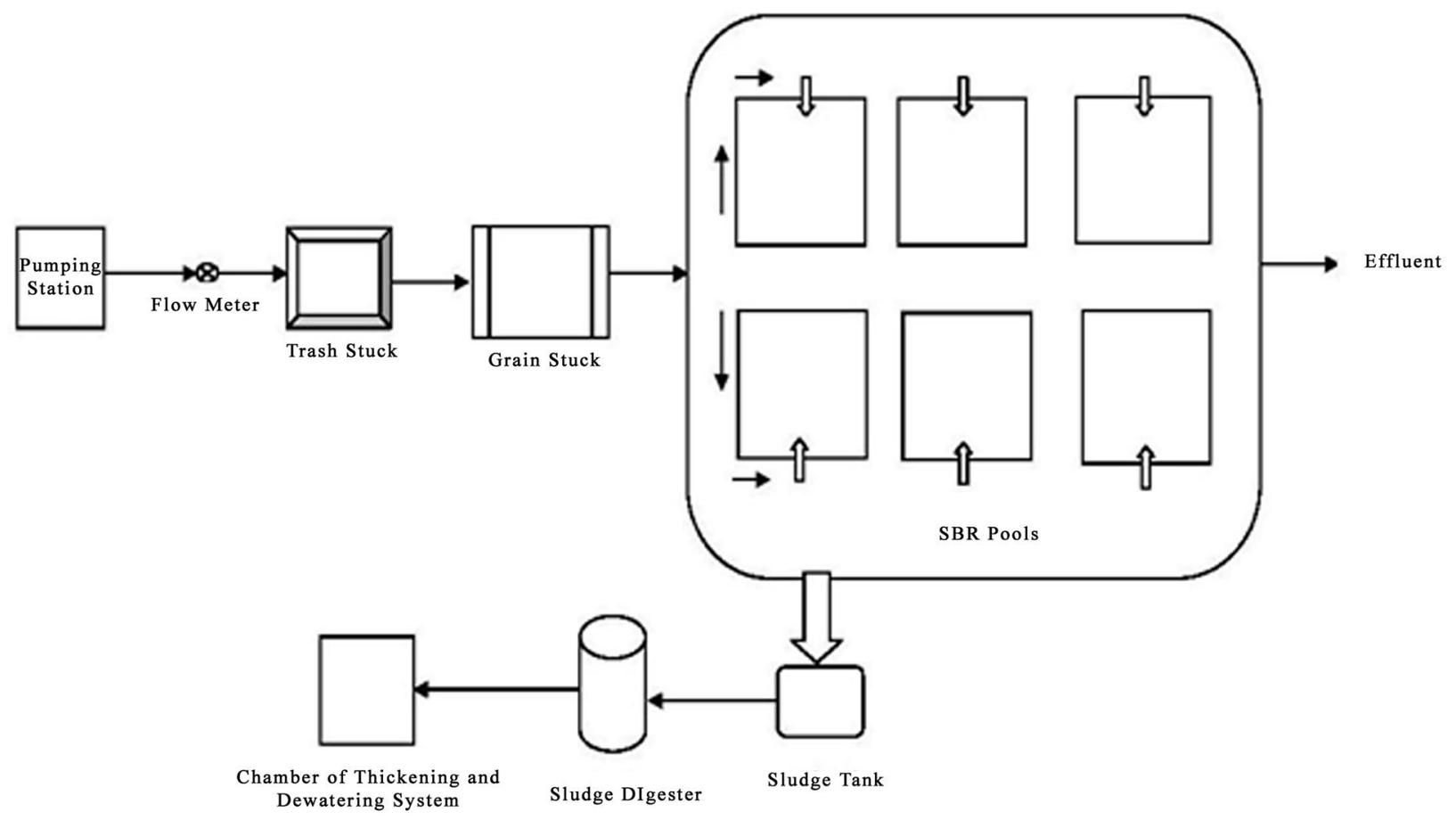

Figure 1. The General Schematic of Yazd Wastewater Treatment Plant 


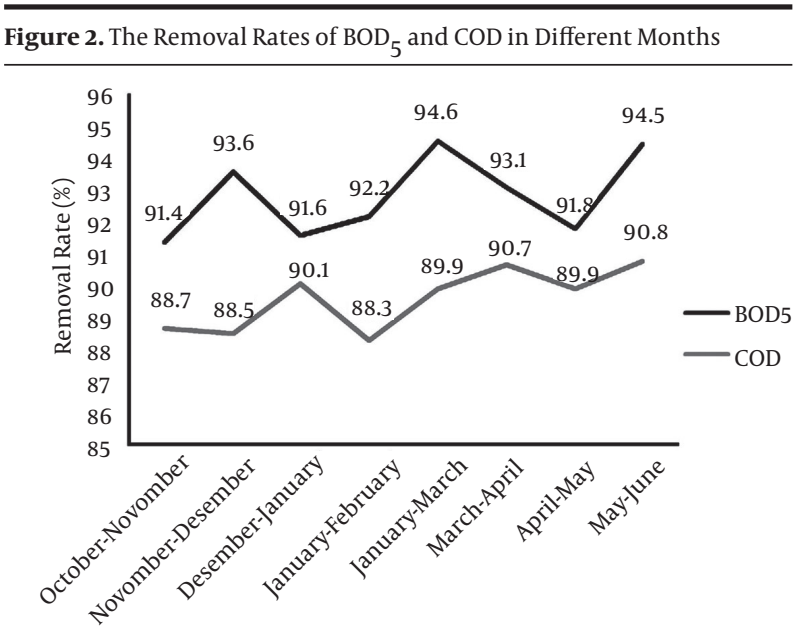

The values are presented as \%.

Figure 3. The Removal Rates of Detergents in Different Months



The values are presented as \%.

Table 1. Quantitative Properties of the Raw Wastewater Entering Yazd Wastewater Treatment Plant ${ }^{\mathrm{a}}$

\begin{tabular}{lc}
\hline Parameter & Mean \\
\hline BOD, mg/L & 232 \\
Population & 150,000 \\
\hline Mean flow rate, $\mathbf{~ m}^{\mathbf{3}} / \mathbf{d}$ & 31950 \\
\hline Maximum flow rate per hour, $\mathbf{~ m}^{\mathbf{3}} / \mathbf{h}$ & 2743 \\
\hline TSS, $\mathbf{m g} / \mathbf{L}$ & 277 \\
TKN, $\mathbf{m g} / \mathbf{L}$ & 40 \\
\hline TP, $\mathbf{m g} / \mathbf{L}$ & 8 \\
\hline a Abbreviations: BOD, biochemical oxygen demand; TSS, total \\
suspended solid; TKN, total kjeldahl nitrogen; and TP, total phosphorus.
\end{tabular}

In this study, the mean input of $\mathrm{BOD}_{5}$ was $292.40 \pm 45.28$ and its output was $20.59 \pm 3.54 \mathrm{mg} / \mathrm{L}$. The mean input and output of COD were respectively $597.15 \pm 97.30$ and 59.34 $\pm 9.47 \mathrm{mg} / \mathrm{L}$. Moreover, based on LAS, the mean input and
Table 2. The Mean Amounts of Input and Output $\mathrm{BOD}_{5}$ and $\mathrm{COD}$ in Different Months a,b

\begin{tabular}{|c|c|c|c|c|}
\hline \multirow[t]{2}{*}{ Months } & \multicolumn{2}{|c|}{$\mathrm{BOD}_{5}, \mathrm{mg} / \mathrm{L}$} & \multicolumn{2}{|c|}{ COD, mg/L } \\
\hline & Input & Output & Input & Output \\
\hline $\begin{array}{l}\text { October- } \\
\text { November }\end{array}$ & $268.21 \pm 40.10$ & $23.10 \pm 3.94$ & $524.10 \pm 91.34$ & $59.2 \pm 9.53$ \\
\hline $\begin{array}{l}\text { November- } \\
\text { December }\end{array}$ & $237.77 \pm 33.91$ & $15.02 \pm 2.85$ & $549.31 \pm 93.82$ & $41.3 \pm 7.82$ \\
\hline $\begin{array}{l}\text { December - } \\
\text { January }\end{array}$ & $251.12 \pm 37.22$ & $21.12 \pm 3.64$ & $563.12 \pm 95.15$ & $62.7 \pm 9.61$ \\
\hline $\begin{array}{l}\text { January- } \\
\text { February }\end{array}$ & $261.50 \pm 38.33$ & $20.2 \pm 3.40$ & $511.70 \pm 90.78$ & $56.2 \pm 8.73$ \\
\hline $\begin{array}{l}\text { February - } \\
\text { March }\end{array}$ & $324.29 \pm 50.75$ & $17.40 \pm 2.92$ & $639.50 \pm 99.77$ & $59.4 \pm 9.41$ \\
\hline $\begin{array}{l}\text { March - } \\
\text { April }\end{array}$ & $393.76 \pm 63.17$ & $25.31 \pm 4.41$ & $814.04 \pm 112.23$ & $64.3 \pm 10.75$ \\
\hline April-May & $259.35 \pm 43.21$ & $24.20 \pm 4.12$ & $563.42 \pm 96.12$ & $75.1 \pm 11.31$ \\
\hline May-June & $357.23 \pm 55.61$ & $18.40 \pm 3.10$ & $612.08 \pm 99.22$ & $56.4 \pm 8.66$ \\
\hline Total Mean & $292.40 \pm 45.28$ & $20.59 \pm 3.54$ & $597.15 \pm 97.30$ & $59.34 \pm 9.47$ \\
\hline
\end{tabular}

Table 3. Amounts of Input and Output Detergents in Different Months ${ }^{\mathrm{a}, \mathrm{b}}$

\begin{tabular}{lcc}
\hline Months & \multicolumn{2}{c}{ Detergent $(\mathrm{LAS}), \mathrm{mg} / \mathrm{L}$} \\
\cline { 2 - 3 } & Input & Output \\
\hline October - November & $2.5 \pm 0.79$ & $0.61 \pm 0.096$ \\
\hline November - December & $2.4 \pm 0.82$ & $0.42 \pm 0.075$ \\
\hline December - January & $3.1 \pm 0.93$ & $0.6 \pm 0.094$ \\
\hline January - February & $3.16 \pm 0.90$ & $0.62 \pm 0.082$ \\
\hline February - March & $5.3 \pm 1.11$ & $0.78 \pm 0.16$ \\
\hline March - April & $3.2 \pm 0.96$ & $0.59 \pm 0.088$ \\
\hline April - May & $2.9 \pm 0.84$ & $0.62 \pm 0.091$ \\
\hline May - June & $3.7 \pm 1.01$ & $0.61 \pm 0.089$ \\
\hline Total mean & $3.29 \pm 0.92$ & $0.60 \pm 0.096$ \\
\hline
\end{tabular}

a Abbreviation: LAS, linear alkyl benzene sulfonates.

$\mathrm{b}$ Values are presented as mean \pm SD.

output of the detergents were $3.29 \pm 0.92$ and $0.606 \pm$ $0.09 \mathrm{mg} / \mathrm{L}$, respectively (Table 4). Finally, the removal efficiencies of $\mathrm{BOD}_{5}$, COD and detergents were respectively 92.95, 90.06 and $81.6 \%$. 
Table 4. Comparing the Mean of the Output Parameters From the SBR System With Standard Published by Iran Department of Environment for Discharge and Reuse of Wastewater $(32,33)^{a}$

\begin{tabular}{lcccc}
\hline Parameters & Values $^{\mathrm{b}}$ & \multicolumn{3}{c}{ Output Standards } \\
\cline { 3 - 5 } & & $\begin{array}{c}\text { Discharge Into Surface } \\
\text { Waters }\end{array}$ & $\begin{array}{c}\text { Discharge Into Absorbent } \\
\text { Wells }\end{array}$ & $\begin{array}{c}\text { No Restriction to Irrigation } \\
\text { Use }\end{array}$ \\
\hline BOD $_{5}$ & $20.59 \pm 3.54$ & 30 & 30 & 100 \\
COD & $59.34 \pm 9.47$ & 60 & 60 & 200 \\
Detergent(LAS) & $0.606 \pm 0.09$ & 1.5 & 1.5 & 1.5 \\
\hline
\end{tabular}

a Abbreviations: $\mathrm{BOD}_{5}$, biochemivcal oxygen demand; COD, chemical oxygen demand; and LAS, linear alkyl benzene sulfonates.

$\mathrm{b}$ Values are presented as mean \pm SD.

\section{Discussion}

The results of the study by Fernandes et al.(2) on domestic wastewater treatment using SBR process with limited air indicated that the removal efficiency of COD was $83 \%$ which is lower than the corresponding value of the present study. This difference can be attributed to different air strategies employed in the two studies (2).

Ghahfarrokhi et al.(34) conducted a study on removal of detergents from hospital wastewaters using SBR method and indicated removal efficiencies of $94.54 \%, 92.97 \%$ and $84.99 \%$ for $\mathrm{BOD}_{5}$, COD and detergents, respectively. These results are in agreement with those of the present study and indicate that in appropriate conditions, SBR system can remove more than $90 \%$ of $\mathrm{BOD}_{5}$ and COD and more than $80 \%$ of detergents from wastewaters (34). In a study on removal efficiency of $\mathrm{BOD}_{5}, \mathrm{COD}$ and detergents, Ehrampoush et al. (35) concluded that artificial subsurface constructed wetland system has lower removal efficiency compared to the SBR system.

Other studies investigated the use of the SBR method in treating different types of industrial wastewaters; however, their results indicated lower removal efficiency of COD compared to the present study $(4,20,23,24)$. Therefore, the SBR system performs better in treating municipal wastewaters that contain organic matters with higher biodegradability compared to industrial wastewaters.

In a study by Pirsaheb et al. (36) the average of LAS removal in extended aeration process in winter and summer were $94.06 \%$ and $99.23 \%$, respectively. In a study by Duarte et al. degradation of LAS in anaerobic SBR (ASBR) was evaluated. Degradation of the surfactant at the end of the operation was $87 \%$ and removal of chemical oxygen demand was $86 \%$ (37). One study encompassed a total of 50 municipal wastewater sites and included 15 activated sludge systems, 12 trickling filters, six oxidation ditches, eight lagoons, and nine rotating biological contactors (RBC). The influent concentrations of LAS for all the treatment plants showed a normal distribution with a mean of $5 \mathrm{mg} / \mathrm{L}$. The average effluent LAS concentrations ranged from $0.04 \mathrm{mg} / \mathrm{L}$ for activated sludge plants to about 1 $\mathrm{mg} / \mathrm{L}$ for trickling filter plants. A range of removal rates over 99\% for activated sludge treatment (11). LAS removal from wastewater by aerobic processes in well-designed municipal wastewater treatment plants was above $90 \%$ (38). As observed, detergents removal efficiency in our system was a little less than other systems that may have been caused by the operation of the wastewater treatment plant in undesirable condition (36).

The presence of surfactants in the influent could cause floc saponification, which decreases the floc dimensions and increases the floc circularity. This results in poor sludge settling and washout of biomass in the system (38). In a study by Rittmann et al. (39) they found that when LAS stays in solution it will rapidly degrade, but slow desorption of LAS initially sorbed to the sludge occurs, which may limit biodegradation rates due to limited bioavailability. Therefore, by increasing the retention time in the aeration stage, the removal efficiency of LAS will increase.

The collected data indicated that the removal efficiencies of $\mathrm{BOD}_{5}$, COD, and detergents were lower in cold months compared to warm ones and this is consistent with Pirsaheb et al. results (36). This can be attributed to the fact that microorganisms are less active in cold environments; therefore, removal efficiency in wastewater treatment systems drops and rises as temperature falls and increases (40).

With the proper operation of the wastewater treatment plant and increasing the retention time, the removal efficiency of detergents increases. According to the environmental standards of $\mathrm{BOD}_{5}, \mathrm{COD}$, and detergents issued by the Department of Environment (32), the results of the present study indicated that the outputs of these parameters were appropriate and standard for agricultural and irrigation uses.

\section{Acknowledgements}

We should express our sincere thanks to Yazd's Organization of Water and Wastewater and all who helped us to conduct the present study better.

\section{Authors' Contributions}

Study concept and design: Hadi Eslami. Acquisition of 
data: Parvaneh Talebi Hematabadi, Seyed Vahid Ghelmani and Akbar Salehi Vaziri. Analysis and interpretation of data: Hadi Eslami and Zahra Derakhshan. Drafting of the manuscript: Hadi Eslami and Zahra Derakhshan. Critical revision of the manuscript for important intellectual content: Hadi Eslami and Zahra Derakhshan. Statistical analysis: Hadi Eslami. Administrative, technical, and material support: Parvaneh Talebi Hematabadi, Seyed Vahid Ghelmani and Akbar Salehi Vaziri. Study supervision: Hadi Eslami.

\section{Funding/Support}

This research was supported by Shahid Sadoughi University of Medical Sciences, Yazd, IR Iran.

\section{References}

1. Hummel D. Handbook of Surfactant Analysis. 2 ed. United States of America: John wiley \& Sons; 2002.

2. Fernandes H, Jungles MK, Hoffmann H, Antonio RV, Costa RH. Full-scale sequencing batch reactor (SBR) for domestic wastewater: performance and diversity of microbial communities. Bioresour Technol. 2013;132:262-8.

3. Mohan SV, Rao NC, Prasad KK, Madhavi BTV, Sharma PN. Treatment of complex chemical wastewater in a sequencing batch reactor (SBR) with an aerobic suspended growth configuration. Process Biochemistry. 2005;40(5):1501-8.

4. Sathian S, Rajasimman M, Radha G, Shanmugapriya V, Karthikeyan C. Performance of SBR for the treatment of textile dye wastewater: Optimization and kinetic studies. Alexandria Engineering Journal. 2014;53(2):417-26.

5. Zeng W, Yang Y, Li L, Wang X, Peng Y. Effect of nitrite from nitritation on biological phosphorus removal in a sequencing batch reactor treating domestic wastewater. Bioresour Technol. 2011;102(12):6657-64.

6. Takdastan A, Pazoki M. Study of biological excess sludge reduction in sequencing batch reactor by heating the reactor. Asian J of Chemistry. 2011;23(1):29-33.

7. Takdastan A, Mehrdadi N, Azimi AA, Torabian A, Nabi Bidhendi G. Investigation of the excess sludge reduction in SBR by oxidizing some sludge by ozone. Iran. J. Chem. Chem. Eng. Vol. 2009;28(4):95-104.

8. Takdastan A, Mehrdadi N, Torabian A, Azimi AA, Bidhendi GN. Investigation of Excess Biological Sludge Reduction in Sequencing Bach Reactor. Asian journal of chemistry. 2009;21(3):2419-27.

9. Pazoki M, Takdastan A, Jaafarzadeh N. Investigation of minimization of excess sludge production in sequencing batch reactor by heating some sludge. Asian Journal of Chemistry. 2010;22(3):1751-9.

10. Takdastan A, Mehrdadi N, Azimi AA, Torabian A, Bidhendi GN. Investigation of intermittent chlorination system in biological excess sludge reduction by sequencing batch reactors. Iranian Journal of Environmental Health Science \& Engineering. 2009;6(1):53-60.

11. Rodezno LAE. Biological treatment of industrial wastewater containing high concentrations of linear alkylbenzene sulfonate (LAS).Honduras: Universidad Nacional Autónoma de Honduras; 2004

12. Ganigue R, Volcke EI, Puig S, Balaguer MD, Colprim J. Impact of influent characteristics on a partial nitritation SBR treating high nitrogen loaded wastewater. Bioresour Technol. 2012;111:62-9.

13. Oliveira RP, Ghilardi JA, Ratusznei SM, Rodrigues JAD, Zaiat M, Foresti E. Anaerobic sequencing batch biofilm reactor applied to automobile industry wastewater treatment: Volumetric loading rate and feed strategy effects. Chemical Engineering and Processing: Process Intensification. 2008;47(8):1374-83.

14. Lamine M, Bousselmi L, Ghrabi A. Biological treatment of grey water using sequencing batch reactor. Desalination. 2007;215(13):127-32.
15. Zhou SQ, Zhang HG, Shi Y. Combined treatment of landfill leachate with fecal supernatant in sequencing batch reactor. $J$ Zhejiang Univ Sci B. 2006;7(5):397-403.

16. Goncalves IC, Penha S, Matos M, Santos AR, Franco F, Pinheiro HM. Evaluation of an integrated anaerobic/aerobic SBR system for the treatment of wool dyeing effluents. Purification of wool dyeing effluent in a SBR. Biodegradation. 2005;16(1):81-9.

17. Mace S, Mata-Alvarez J. Utilization of SBR Technology for Wastewater Treatment: An Overview. Industrial \& Engineering Chemistry Research. 2002;41(23):5539-53.

18. Chiavola A, Farabegoli G, Antonetti F. Biological treatment of olive mill wastewater in a sequencing batch reactor. Biochemical Engineering Journal. 2014;85:71-8.

19. Elmolla ES, Chaudhuri M. The feasibility of using combined TiO2 photocatalysis-SBR process for antibiotic wastewater treatment Desalination. 2011;272(1-3):218-24.

20. Sirianuntapiboon S, Chairattanawan K, Rarunroeng M. Biological removal of cyanide compounds from electroplating wastewater (EPWW) by sequencing batch reactor (SBR) system. J Hazard Mater. 2008;154(1-3):526-34.

21. Fu L, Wen X, Yi Qian QL. Treatment of dyeing wastewater in two SBR systems. Process Biochemistry. 2001;36(11):1111-8.

22. Yoong ET, Lant PA, Greenfield PF. In situ respirometry in an SBR treating wastewater with high phenol concentrations. Water Research. 2000;34(1):239-45.

23. Maranon E, Vazquez I, Rodriguez J, Castrillon L, Fernandez Y, Lopez H. Treatment of coke wastewater in a sequential batch reactor (SBR) at pilot plant scale. Bioresour Technol. 2008;99(10):4192-8.

24. Mojiri A, Aziz HA, Zaman NQ, Aziz SQ, Zahed MA. Powdered ZELIAC augmented sequencing batch reactors (SBR) process for cotreatment of landfill leachate and domestic wastewater. JEnviron Manage. 2014;139:1-14.

25. Stackelberg PE, Gibs J, Furlong ET, Meyer MT, Zaugg SD, Lippincott RL. Efficiency of conventional drinking-water-treatment processes in removal of pharmaceuticals and other organic compounds. Sci Total Environ. 2007;377(2-3):255-72.

26. Ying GG. Fate, behavior and effects of surfactants and their degradation products in the environment. Environ Int. 2006;32(3):417-31.

27. Ebrahimi A, Ehrampoosh M, Samaie M, Ghelmani S, Talebi P, Dehghan M, et al. Removal Efficiency of Linear Alkyl Benzene Sulfonate (LAS) in Yazd Stabilization Pond. Sci Info Database, Iran. 2010;21(76):38-43.

28. Hosseini F, Malekzadeh F, Amirmozafari N, Ghaemi N. Biodegradation of anionic surfactants by isolated bacteria from activated sludge. In J of Environment Scie \& Tech. 2007;4(1):127-32.

29. Justin MZ, Vrhovsek D, Stuhlbacher A, Bulc TG. Treatment of wastewater in hybrid constructed wetland from the production of vinegar and packaging of detergents. Desalination. 2009;246(1-3):100-9.

30. Mensah KA, Forster CF. An examination of the effects of detergents on anaerobic digestion. Bioresour Technol. 2003;90(2):133-8.

31. Rice EW, Bridgewater L. Standard methods for the examination of water and wastewater.Washington, DC: American Public Health Association Washington, DC; 2012.

32. IDE.. [Iran Department of Environment for discharge and reuse of wastewater]. In: Environment IDo editor. . Iran: Depatrment of Iran Environmental Protection Publications; 1999.

33. Nasseri S, Sadeghi T, Vaezi F, Naddafi K. Evaluation Of The Possible Options For Reuse Of Ardebil Wastewater Treatment Plant Effluent. Iran J of Environment Health Sci \& Engineering. 2008;5(4):297-304.

34. Ghahfarrokhi BB, Ehramposh MH, Nasiri P, Ghasemee A, RezaeeJavanmardi R. Survey of amount of removed detergents and organic Materials of hospital wastewater with SBR developed method (case study of Yazd city).JEST. 2010;12(2):61-70.

35. Ehrampoush MH, Karimi B, Rahimi S, Talebi P, Ghelmani V. A study of the removal rate of linear detergents and organics via subsurface constructed wetland from Yazd wastewater. Toloo-eBehdasht. 2007;6(3-4):74-84.

36. Pirsaheb M, Khamutian R, Dargahi A. Efficiency of Activated Sludge Process (Extended Aeration) in Removal of Linear Alkyl Benzene Sulfonate(LAS) from Municipal Wastewater-Case Study: 


\section{Eslami H et al.}

Wastewater Treatment of Paveh City. $j$ of health. 2013;4(3):249-59.

37. Duarte ICS, De-Oliveira LL, Okada DY, Do-Prado PF, Varesche MBA Evaluation of the microbial diversity in sequencing batch reactor treating linear alkylbenzene sulfonate under denitrifying and mesophilic conditions using swine sludge as inoculum. Brazil Archives of Biol and Technol. 2015:1-7.

38. Kwok T. .Assessing the effect of surfactants on activated sludge processes using sequencing batch reactors.. Australia: RMIT University; 2011.
39. Rittmann BE, Tularak P, Lee KC, Federle TW, Itrich NR, Kaiser SK, et al. How adaptation and mass transfer control the biodegradation of linear alkylbenzene sulfonate by activated sludge. Biodegradation. 2001;12(1):31-7.

40. Daraghi A, Pirsaheb M, Savadpoor M, Alighaderi M, Farokhi M. Effect of retention time and temperature on the efficiency stabilization ponds in treatment of petroleum wastewater. JEST. 2014;16(2):13-24. 